\title{
PENGARUH BUDAYA ORGANISASI, KEPUASAN KERJA DAN GAYA KEPEMIMPINAN TERHADAP KINERJA KARYAWAN DENGAN KOMITMEN ORGANISASIONAL SEBAGAI VARIABEL INTERVERNING
}

\section{THE EFFECT OF ORGANIZATIONAL CULTURE, WORK SATISFACTION AND LEADERSHIP STYLE ON EMPLOYEE PERFORMANCE WITH ORGANIZATIONAL COMMITMENTS AS INTERVERNING VARIABLES}

\author{
Sri Sumarwinati ${ }^{1}$, Sri Langgeng Ratnasari ${ }^{2}$ \\ ${ }^{1,2}$ (Prodi Magister Manajemen, Program Pascasarjana, Universitas Riau Kepulauan) \\ ${ }^{1}$ srisumarwinati@gmail.com,${ }^{2}$ sarisucahyo@yahoo.com
}

\begin{abstract}
Abstrak
Penelitian ini untuk menguji pengaruh Budaya Organisasi dan Gaya Kepemimpinan terhadap Kepuasan Kerja, menguji pengaruh Kepuasan Kerja terhadap Komitmen Organisasional, dan menguji pengaruh Budaya Organisasi, Gaya Kepemimpinan, dan Kepuasan kerja terhadap Kinerja Karyawan melalui Komitmen Organisasional sebagai variabel interverning. Sampel penelitian ini adalah karyawan Dinas Kelautan, Perikanan, Pertanian dan Kehutanan Kota Batam sejumlah 100 orang. Teknik analisis menggunakan Structural Equation Model (SEM) dengan AMOS. Hasil analisis menunjukkan bahwa Budaya Organisasi dan Gaya Kepemimpinan berpengaruh positif dan signifikan terhadap Kepuasan Kerja, Kepuasan Kerja berpengaruh positif dan signifikan terhadap Komitmen Organisasional, Budaya Organisasi berpengaruh positif dan signifikan terhadap Kinerja karyawan, Gaya Kepemimpinan berpengaruh positif dan signifikan terhadap Kinerja Karyawan dan Budaya Organisasi, Kepuasan Kerja dan Gaya Kepemimpinan melalui Komitmen Organisasional berpengaruh postif terhadap Kinerja Karyawan. Temuan Empiris tersebut mengindikasikan bahwa untuk meningkatkan Kepuasan Kerja, Komitmen Organisasional, Gaya Kepemimpinan dan Budaya Organisasi yang merupakan penyebab terjadinya Kinerja Karyawan yang rendah, manajemen perusahaan seharusnya memperhatikan faktor-faktor seperti Budaya Organisasi, Kepuasan Kerja, Gaya Kepemimpinan dan Komitmen Organisasional, karena faktor-faktor tersebut terbukti mempengaruhi tinggi rendahnya Kepuasan Kerja, Komitmen Organisasi dan Kinerja Karyawan tersebut. Implikasi teoritis dan saran-saran bagi penelitian yang akan datang juga diuraikan pada bagian akhir dalam penelitian ini.
\end{abstract}

Kata Kunci: Budaya Organisasi, Gaya Kepemimpinan, Komitmen Organisasional, Kepuasan Kerja, Kinerja Karyawan

\begin{abstract}
The purpose of this research is to test influences of Organization Culture, Leadership Style toward Job Satisfaction, Job Satisfaction toward Organizational Commitment, and Organization Culture, Leadership Style and Job Satisfaction toward Employee's Performance using Organizational Commitment to be variabel interverning. The samples of this research consisted of one hundred employees's Dinas Kelautan, Perikanan, Pertanian dan Kehutanan Kota Batam. Analysis technique use Structural Equation Model with AMOS software. The result of the analysis showed that Organization Culture and Leadership Style contributes an positive influence which is significant to Job Satisfaction, Job Satisfaction contributes an positive influence which is significant to Organizational Commitment, Organization Culture contributes an positive influence which is significant to Employee's Performance, Leadership Style contributes an positive influence which is significant to Employee's Performance, Organization Culture, Leadership Style and Job Satisfaction contributes an positive influence which is significant to Employee's Performance using Organizational Commitment to be variabel interverning. This empirical result indicated that in order to raise the standarts of a Organization Culture, Leadership Style and Job Satisfaction also Organizational Commitment, because the lower of Employee's Performance, management should focus on factor such as Culture, Leadership Style, Job Satisfaction and Organizational Commitment because leverage Organization Commitment, Job Satisfaction and Employee's Performance depend on it. Theoritical implications and suggestions for future research have been elaborated at the end of this study.
\end{abstract}

Key words: Organization Culture, Leadership Style, Job Satisfaction, Organizational Commitment, Employee's Performance 


\section{PENDAHULUAN}

Salah satu masalah nasional yang dihadapi oleh bangsa Indonesia saat ini adalah penanganan terhadap rendahnya kualitas sumber daya manusia. Jumlah sumber daya manusia yang besar apabila digunakan secara efektif dan efisien, hal ini akan bermanfaat untuk menunjang gerak lajunya pembangunan nasional yang berkelanjutan. Melimpahnya sumber daya manusia yang ada saat ini mengharuskan berfikir secara seksama yaitu bagaimana dapat memanfaatkan sumber daya manusia secara optimal. Agar di masyarakat memiliki sumber daya manusia yang handal, maka diperlukan pendidikan yang berkualitas, penyediaan berbagai fasilitas sosial, lapangan pekerjaan yang memadai. Kelemahan dalam penyediaan berbagai fasilitas tersebut akan menyebabkan keresahan sosial yang akan berdampak kepada keamanan masyarakat. Saat ini kemampuan sumber daya manusia masih rendah baik dilihat dari kemampuan intelektualnya maupun keterampilan teknis yang dimilikinya.

Kualitas sumber daya manusia akan terpenuhi apabila kepuasan kerja sebagai unsur yang berpengaruh terhadap kinerja dapat tercipta dengan sempurna. Membahas kepuasan kerja tidak akan terlepas dengan adanya faktor-faktor yang dapat mempengaruhi kepuasan kerja seseorang. Agar kepuasan karyawan selalu konsisten maka setidak-tidaknya perusahaan selalu memperhatikan lingkungan di mana karyawan melaksanakan tugasnya misalnya rekan kerja, pimpinan, suasana kerja dan hal-hal lain yang dapat mempengaruhi kemampuan seseorang dalam menjalankan tugasnya.

Masalah budaya itu sendiri merupakan hal yang esensial bagi suatu organisasi atau perusahaan, karena akan selalu berhubungan dengan kehidupan yang ada dalam perusahaan. Budaya organisasi merupakan falsafah, ideologi, nilai-nilai, anggapan, keyakinan, harapan, sikap dan norma-norma yang dimiliki secara bersama serta mengikat dalam suatu komunitas tertentu. Secara spesifik budaya dalam organisasi akan ditentukan oleh kondisi kerja tim, kepemimpinan dan karakteristik organisasi serta proses administrasi yang berlaku.

Dalam organisasi tentunya banyak faktor yang mempengaruhi seseorang untuk mencapai tujuan yang telah ditetapkan, sedangkan jalannya organisasi atau perusahaan tentunya diwarnai oleh perilaku individu yang merasa berkepentingan dalam kelompoknya masing-masing. Perilaku individu yang berada dalam organisasi atau perusahaan tentunya sangat mempengaruhi organisasi baik secara langsung maupun tidak langsung, hal ini akibat adanya kemampuan individu yang berbeda-beda dalam menghadapi tugas atau aktivitasnya. 
Setiap manusia atau seseorang selalu mempertimbangkan perilakunya terhadap segala apa yang diinginkan agar dapat tercapai tanpa menimbulkan konflik baik secara individu maupun kelompok, sehingga kinerja dapat tercapai sesuai dengan yang diinginkan.

Research gap dari penelitian ini adalah perluasan dari variabel-variabel penelitian yang mempengaruhi kepuasan kerja. Menurut Samad (2005) kepuasan kerja berpengaruh positif terhadap komitmen organisasional, menurut Kadir dan Didik (2003) komitmen berpengaruh positif terhadap kepuasan kerja, menurut Lund (2003) yang mempengaruhi kepuasan kerja adalah budaya organisasi, menurut Cahyono dan Ghozali (2002) komitment organisasional mempengaruhi kepuasan kerja karyawan, menurut Koesmono (2005) variabel yang mempengaruhi kepuasan kerja adalah motivasi dan budaya organisasi, sedangkan menurut Pool (1997) yang mempengaruhi kepuasan kerja adalah gaya kepemimpinan, dan motivasi kerja. Penelitian ini juga merupakan perluasan dari variabel-variabel penelitian yang mempengaruhi kinerja karyawan, menurut Yuwalliatin (2006) kinerja karyawan dipengaruhi oleh komitmen, motivasi, dan budaya organisasi, menurut Masrukhin dan Waridin (2006) yang mempengaruhi kinerja karyawan adalah motivasi kerja, kepuasan kerja, budaya organisasi dan kepemimpinan, menurut Koesmono (2005) kinerja karyawan dipengaruhi oleh motivasi, budaya organisasi dan kepuasan kerja. Menurut Samad (2005) kinerja karyawan dipengaruhi oleh kepuasan kerja dan komitmen organisasi.

Pada pembahasan ini mengangkat permasalahan yang terjadi pada Dinas Kelautan, Perikanan, Pertanian dan Kehutanan Kota Batam. Penelitian yang sama tentang kinerja karyawan di Dinas Kelautan, Perikanan, Pertanian dan Kehutanan Kota Batam sudah pernah ada. Penelitian sebelumnya hanya meneliti pengaruh budaya organisasi terhadap kinerja karyawan melalui variabel intervening kepuasan kerja. Akan dilakukan penelitian kembali pengaruh budaya organisasi dan kepuasan kerja dengan menambahkan variabel gaya kepemimpinan dan komitmen organisasional yang bertujuan untuk meningkatkan kinerja Karyawan Dinas Kelautan, Perikanan, Pertanian dan Kehutanan serta meneliti tingkat kepuasan kerja karyawan di Dinas Kelautan, Perikanan, Pertanian dan Kehutanan

Karyawan yang hadir melebihi pukul 07.15 (batas toleransi) cukup tinggi, sedangkan pada saat pulang beberapa karyawan yang datang terlambat tidak menambah waktu pulangnya, misalnya dia datang pukul 07.16, sebaiknya dia pulang pukul 16.16. Pada bulan september dan bulan oktober pada saat bulan Ramadhan, jam kerja di Dinas Kelautan, Perikanan, Pertanian dan Kehutanan jam 7.30, tetapi masih ada beberapa karyawan yang 
masih datang terlambat walaupun sedikit berkurang dari biasanya. Rata-rata karyawan yang masih sering datang terlambat tiap bulannya adalah 27 karyawan yang sama. Hal ini dapat mempengaruhi produktivitas karyawan Dinas Kelautan, Perikanan, Pertanian dan Kehutanan.

\section{Tujuan Penelitian}

Tujuan yang hendak dicapai pada penelitian ini adalah:

1. Menganalisis dan membuktikan pengaruh budaya organisasi terhadap kepuasan kerja karyawan

2. Menganalisis dan membuktikan pengaruh gaya kepemimpinan terhadap kepuasan kerja karyawan

3. Menganalisis dan membuktikan pengaruh kepuasan kerja terhadap komitmen organisasional

4. Menganalisis dan membuktikan komitmen organisasional terhadap kinerja karyawan

5. Menganalisis dan membuktikan pengaruh budaya organisasi terhadap kinerja karyawan

6. Menganalisis dan membuktikan pengaruh gaya kepemimpinan terhadap kinerja karyawan

\section{TINJAUAN PUSTAKA}

\section{Kinerja Karyawan}

Menurut Mangkunegara (2001); kinerja dapat didefinisikan sebagai hasil kerja secara kualitas dan kuantitas yang dapat dicapai oleh seseorang karyawan dalam melaksanakan tugas sesuai dengan tanggung jawab yang diberikan kepadanya. Cascio (1995) dalam Koesmono (2005) mengatakan bahwa kinerja merupakan prestasi karyawan dari tugastugasnya yang telah ditetapkan. Soeprihantono (1998); mengatakan bahwa kinerja merupakan hasil pekerjaan seorang karyawan selama periode tertentu dibandingkan dengan berbagai kemungkinan, misalnya standard, target/sasaran/criteria yang telah ditentukan terlebih dahulu dan telah disepakati bersama.

\section{Budaya Organisasi}

Budaya telah didefinisikan dengan berbagai cara, namun belum dapat ditentukan definisinya secara pasti (Ouchi dan Wilkins, 1985 dalam Dwi Cahyono dan Imam Ghozali, 2002). Budaya merupakan norma-norma dan nilai-nilai yang mengarahkan perilaku anggota organisasi (Luthans, 1998). Setiap orang akan berperilaku sesuai dengan budaya yang berlaku agar diterima di lingkungannya. 


\section{Gaya Kepemimpinan}

Robbins (1996) menyatakan bahwa kepemimpinan merupakan kemampuan untuk mempengaruhi suatu kelompok kearah tercapainya suatu tujuan. Kepemimpinan adalah pengaruh

antara pribadi yang dijalankan dalam situasi tertentu, serta diarahkan melalui proses komunikasi ke arah pencapaian satu atau beberapa tujuan tertentu. Kepeminpinan menyangkut proses pengaruh sosial yang disengaja dijalankan oleh seseorang terhadap orang lain untuk menstruktur aktivitas dan pengaruh di dalam sebuah kelompok atau organsiasi.

\section{Kepuasan Kerja}

Menurut Dole and Schroeder (2001); Kepuasan kerja dapat didefinisikan sebagai perasaan dan reaksi individu terhadap lingkungan pekerjaannya, sedangkan menurut Testa (1999); kepuasan kerja merupakan kegembiraan atau pernyataan emosi yang positif hasil dari penilaian salah satu pekerjaan atau pengalaman-pengalaman pekerjaan.

Menurut Ardiyanto (2003) menggambarkan kepuasan kerja adalah "memiliki sikap positif terhadap pekerjaan pada diri seseorang". Bukti-bukti penelitian terhadap kepuasan kerja dapat dibagi menjadi beberapa kategori seperti kepemimpinan, kebutuhan psikologis, penghargaan atas usaha, manajemen idiologi dan nilai-nilai, faktor-faktor rancangan pekerjaan dan muatan kerja.

\section{Komitmen Organisasional}

Steers dalam (Yuwalliatin, 2006) mendefinisikan komitmen organisasi sebagai rasa identifikasi, keterlibatan, dan loyalitas yang dinyatakan oleh seorang karyawan terhadap organisasinya. Steers berpendapat bahwa komitmen organisasi merupakan kondisi dimana karyawan sangat tertarik terhadap tujuan, nilai-nilai dan sasaran organisasi. Komitmen terhadap organisasi artinya lebih dari sekedar keanggotaan formal, karena meliputi sikap menyukai organisasi dan kesediaan untuk mengusahakan tingkat upaya yang tinggi bagi kepentingan organisasi demi pencapaian tujuan.

Gibson, dalam Yuwalliatin (2006) memberikan pengertian bahwa: "komitmen karyawan merupakan suatu bentuk identifikasi, loyalitas dan keterlibatan yang diekspresikan oleh karyawan terhadap organisasi. Sedangkan Mathis \& Jackson dalam Yuwalliatin (2006) memberikan pengertian bahwa : "komitmen organisasional merupakan tingkat kepercayaan dan penerimaan tenaga kerja terhadap tujuan organisasi dan mempunyai keinginan untuk tetap ada di dalam organisasi tersebut". 


\section{Metode Penelitian}

\section{Rancangan Penelitian}

Jenis penelitian ini adalah penelitian yang bermaksud menjelaskan kedudukankedudukan variable dengan variable lain. Penelitian ini termasuk pada penelitian asosiatif hubungan yang berfungsi untuk menjelaskan, meramalkan dan mengontrol suatu gejala penelitian (Sugiyono, 2006). Penelitian ini bersifat eksplanotory yaitu tipe penelitian yang menjelaskan antara variable-variabel yang ada yaitu variable Budaya Organisasi, Kepuasan Kerja, Gaya Kepemimpinan, Kinerja Karyawan, Komitmen Organisional. Dengan teknik pengumpulan awal yaitu observasi awal, penelitian kepustakaan dan penelitian lapangan dengan menyebarkan instrument penelitian berupa anket dengan berskala linkert kepada sampel sebanyak 100 orang karyawan Dinas Kelautan, Perikanan, Pertanian dan Kehutanan Kota Batam.

\section{Teknik Analisis Data}

Penelitian membutuhkan suatu analisis data dan interpretasi yang akan digunakan untuk menjawab pertanyaan-pertanyaan penelitian untuk mengungkap fenomena sosial tertentu. Sehingga analisis data adalah proses penyederhanaan data kedalam bentuk lebih mudah dibaca dan diinterpretasikan.

Model yang akan digunakan dalam penelitian ini adalah model struktur berjenjang dan untuk menguji hipotesis yang diajukan, maka teknik analisis yang digunakan adalah SEM (Structural Equation Modelling) yang dioperasikan melalui program AMOS 4.01. Alasan yang dikemukakan berkaitan dengan pemakaian SEM, karena SEM merupakan sekumpulan teknik statistical yang memungkinkan pengujian sebuah rangkaian hubungan yang relatif 'rumit' secara simultan.

\section{HASIL PENELITIAN DAN PEMBAHASAN}

Langkah-langkah yang harus dilakukan untuk menganalisis sebuah model yang telah dikembangkan pada bab sebelumnya. Sistematika bahasan dalam bab ini mencakup jenis dan sumber data, populasi dan sampel, metode pengumpulan data dan teknik analisis data.

\section{Jenis dan Sumber Data}

Penelitian ini menggunakan data yang diperoleh melalui responden, dimana responden akan memberikan respon verbal dan atau respon tertulis sebagai tanggapan atas pernyataan yang diberikan.

Adapun jenis data yang digunakan dalam penelitian ini adalah: 
1. Data Primer, adalah data mengenai pendapat responden tentang gaya kepemimpinan, budaya organisasi, komitmen organisasional, kepuasan kerja dan kinerja karyawan yang diperoleh secara langsung dari responden dengan memeberikan tanggapan atas pernyataan kuesioner. Dalam penelitian ini kuesioner dibagikan langsung pada responden.

2. Data Sekunder, adalah data yang diperoleh secara tidak langsung melalui perantara (diperoleh dan dicatat oleh pihak lain). Dalam penelitian ini, data sekunder hanya mendukung pengumpulan data awal sebagai output penelitian. Data sekunder yang dimaksud adalah data tingkat absensi karyawan, buku pedoman perilaku karyawan Dinas KP2K Kota Batam

\section{Populasi dan Sampling}

Populasi yaitu sekelompok orang, kejadian, atau segala yang mempunyai karakteristik tertentu (Supomo dan Indriantono, 1998). Adapun yang menjadi alasan objek penelitian ini adalah seluruh karyawan di bagian pemasaran, niaga, distribusi, keuangan, SDM dan administrasi yang masih bekerja dan telah memiliki pengalaman kerja tiga tahun atau lebih. Karyawan yang telah memiliki pengalaman kerja tiga tahun atau lebih telah mengalami penyesuaian yang relatif stabil terhadap budaya organisasi, dan gaya kepemimpinan. Karyawan yang memiliki pengalaman kerja tiga tahun diharapkan memiliki tingkat komitmen yang tinggi. Jumlah populasi adalah 187 karyawan dengan masa kerja tiga tahun atau lebih. Untuk kuesioner kinerja karyawan diisi oleh Kabid masing-masing bidang. Karena keterbatasan maka penelitian dilakukan secara sampling.

Hair et. al. (1995) mengatakan semakin banyak sampel yang dipakai maka akan semakin baik. Walaupun demikian, apabila sampel terlalu besar (misal 1000 sampel) maka akan menyulitkan untuk mendapatkan model yang cocok. Berdasarkan hal tersebut, maka penentuan jumlah sampel adalah 5 - 10 kali indikator yang diukur. Sampel yang diambil adalah sebagian dari populasi yang telah ditentukan dan karena indikatornya berjumlah 20 maka sampel yang diambil minimal 100.

\section{Metode Pengumpulan Data}

Metode pengumpulan data yang akan digunakan dalam penelitian ini adalah menggunakan kuesioner. Metode ini memberikan tanggung jawab kepada responden untuk membaca dan memberi tanggapan atas pernyataan dari kuesioner dapat memberikan penjelasan mengenai tujuan survei dan pernyataan yang kurang dipahami oleh responden. 
Kuesioner dapat langsung dikumpulkan, setelah selesai diisi oleh responden. Hasil dari kuesioner digunakan untuk mendapatkan data tentang dimensi-dimensi dari konstrukkonstruk yang sedang dikembangkan dalam penelitian ini. Pernyataan-pernyataan dalam kuesioner diukur dengan menggunakan skala 1-7 untuk mendapatkan data yang bersifat interval dan diberi skor atau nilai sebagai berikut:

$1 \_2 \_3 \_4 \_5 \_6 \_7$

\section{Sangat Tidak Setuju}

Sangat Setuju

\section{Uji Reliabilitas dan Validitas}

Uji Reliabilitas merupakan uji kehandalan yang bertujuan untuk mengetahui seberapa jauh sebuah alat ukur dapat diandalkan atau dipercaya. Kehandalan berkaitan dengan estimasi sejauh mana suatu alat ukur, apabila dilihat dari stabilitas atau konsistensi internal dari jawaban atau pernyataan jika pengamatandilakukan secara berulang. Apabila suatu alat ukur digunakan berulang dan hasil yang diperoleh relatif konsisten maka alat ukur tersebut dianggap handal (reliabilitas). Pengujian reliabilitas terhadap seluruh item/pernyataan yang dipergunakan pada penelitian ini akan menggunakan formula Cronbach alpha (koefisien alfa Cronbach), dimana secara umum dianggap reliable apabila nilai alfa cronbachnya > 0.6 (Hair et. Al, 1995) untuk mendapatkan nilai yang tingkat reliabilitas dimensi pembentuk vairabel laten.

Uji validitas dilakukan dengan tujuan mengetahui ketepatan kuesioner, kehandalan kuesioner mempunyai arti bahwa kuesioner mampu mengukur apa yang seharusnya diukur. Hasil dari uji ini cukup mencerminkan topik yang sedang diteliti. Uji validitas diuji dengan program SPSS dengan melihat korelasi Pearson's Product Moment untuk masing-masing item pernyataan dengan totalnya.

\section{Teknik Analisis Data}

Penelitian membutuhkan suatu analisis data dan interpretasi yang akan digunakan untuk menjawab pertanyaan-pertanyaan penelitian untuk mengungkap fenomena sosial tertentu. Sehingga analisis data adalah proses penyederhanaan data kedalam bentuk lebih mudah dibaca dan diinterpretasikan.

Model yang akan digunakan dalam penelitian ini adalah model struktur berjenjang dan untuk menguji hipotesis yang diajukan, maka teknik analisis yang digunakan adalah 
SEM (Structural Equation Modelling) yang dioperasikan melalui program AMOS 4.01. Alasan yang dikemukakan berkaitan dengan pemakaian SEM, karena SEM merupakan sekumpulan teknik statistical yang memungkinkan pengujian sebuah rangkaian hubungan yang relatif 'rumit' secara simultan.

Pemodelan melalui SEM juga memungkinkan seorang peneliti dapat menjawab pertanyaan penelitian yang bersifat regresif maupun dimensional (yaitu mengukur apa dimensi-dimensi dari sebuah konsep) (Ferdinand, 2005). Menganalisis model penelitian dengan SEM dapat mengidentifikasi dimensi-dimensi sebuah konstruk dan pada saat yang sama mengukur pengaruh atau derajat hubungan antar faktor yang telah diidentifikasi dimensi-dimensinya.

\section{Analisis Structural Equation Model (SEM)}

Analisis selanjutnya adalah analisis Structural Equation Model (SEM) secara full model, setelah dilakukan analisis terhadap tingkat validitas dari indikator-indikator pembentuk variabel laten yang diuji dengan confirmatory factor analysis. Analisis hasil pengolahan data pada tahap full model SEM dilakukan dengan melakukan uji kesesuaian dan uji statistik.

Uji terhadap hipotesis model menunjukkan bahhwa model ini sesuai dengan data atau fit terhadap data yang digunakan dalam penelitian adalah seperti terlihat pada tabel berikut ini :

Tabel 1 Hasil Pengujian Kelayakan Model Structural Equation Model (SEM)

\begin{tabular}{|l|c|c|c|}
\hline $\begin{array}{l}\text { Goodness of Fit } \\
\text { Indeks }\end{array}$ & Cut-off Value & Hasil Analisis & Evaluasi Model \\
\hline Chi - Square & $(<193.791)$ & 190.843 & Baik \\
\hline Probability & $\geq 0.05$ & 0.067 & Baik \\
\hline RMSEA & $\leq 0.08$ & 0.042 & Baik \\
\hline GFI & $\geq 0.90$ & 0.847 & Kurang Baik \\
\hline AGFI & $\geq 0.90$ & 0.803 & Kurang Baik \\
\hline TLI & $\geq 0.95$ & 0.975 & Baik \\
\hline CFI & $\geq 0.95$ & 0.979 & Baik \\
\hline
\end{tabular}

Sumber: Data penelitian yang diolah 
Hasil analisis pengolahan data terlihat bahwa semua konstruk yang digunakan untuk membentuk sebuah model penelitian, pada proses analisis full model SEM telah memenuhi kriteria goodness of fit yang telah ditetapkan. Nilai probability pada analisis ini menunjukkan nilai diatas batas signifikansi yaitu sebesar 0.067 atau diatas 0.05 , nilai ini menunjukkan tidak adanya perbedaan antara matriks kovarian sample dengan matriks kovarian populasi yang diestimasi. Ukuran goodness of fit lain juga menunjukkan pada kondisi yang baik meskipun GFI dan AGFI belum mencapai nilai 0,90.

Untuk uji statistik terhadap hubungan antar variabel yang nantinya digunakan sebagai dasar untuk menjawab hipotesis penelitian yang telah diajukan. Uji statistik hasil pengolahan dengan SEM dilakukan dengan melihat tingkat signifikansi hubungan antar variable yang ditampakkan melalui nilai Probabilitas (p) dan dan Critical Ratio (CR) masingmasing hubungan antar variabel. Namun demikian untuk mendapatkan model yang baik, akan terlebih dahulu diuji masalah penyimpangan terhadap asumsi SEM.

\section{Pengujian Hipotesis}

\section{Pengujian Hipotesis 1}

Parameter estimasi hubungan variabel budaya organisasi dengan kepuasan kerja tersebut diperoleh sebesar 0,473. Pengujian menunjukkan hasil yang signifikan dengan nilai C. $R=4.250$ dengan probabilitas $=0,000$. Nilai probabilitas pengujian berada di bawah 0,05. Dengan demikian Hipotesis 1 diterima

\section{Pengujian Hipotesis 2}

Parameter estimasi hubungan variabel gaya kepemimpinan dengan kepuasan kerja tersebut diperoleh sebesar 0,395. Pengujian menunjukkan hasil yang signifikan dengan nilai C.R

1.3.617 dengan probabilitas $=0,000$. Nilai probabilitas pengujian berada di bawah 0,05 . Dengan demikian Hipotesis 2 diterima

\section{Pengujian Hipotesis 3}

Parameter estimasi hubungan variabel kepuasan kerja dengan komitmen organisasi diperoleh sebesar 0,571. Pengujian menunjukkan hasil yang signifikan dengan nilai C.R = 5.509 dengan probabilitas $=0,000$. Nilai probabilitas pengujian berada di bawah 0,05. Dengan demikian Hipotesis 3 diterima

\section{Pengujian Hipotesis 4}


Parameter estimasi hubungan variabel komitmen organisasi dengan kinerja karyawan diperoleh sebesar 0,343. Pengujian menunjukkan hasil yang signifikan dengan nilai C.R = 3.203 dengan probabilitas $=0,001$. Nilai probabilitas pengujian berada di bawah 0,05. Dengan demikian Hipotesis 4 diterima

\section{Pengujian Hipotesis 5}

Parameter estimasi hubungan variabel komitmen organisasi dengan kinerja karyawan diperoleh sebesar 0,365. Pengujian menunjukkan hasil yang signifikan dengan nilai C.R = 3.123 dengan probabilitas $=0,002$. Nilai probabilitas pengujian berada di bawah 0,05 . Dengan demikian Hipotesis 5 diterima

\section{Pengujian Hipotesis 6}

Parameter estimasi hubungan variabel komitmen organisasi dengan kinerja karyawan diperoleh sebesar 0,317. Pengujian menunjukkan hasil yang signifikan dengan nilai C.R = 2.764 dengan probabilitas $=0,006$. Nilai probabilitas pengujian berada di bawah 0,05 . Dengan demikian Hipotesis 6 diterima

\section{Efek langsung dan Tidak Langsungnya}

Efek langsung dan tidak langsung dari hasil penelitian ini adalah Efek langsung budaya organisasi terhadap kepuasan kerja sebesar 0,461, gaya kepemimpinan terhadap kepuasan kerja sebesar 0,383, efek langsung kepuasan kerja terhadap komitmen organisasi sebesar 0,602, pengaruh langsung budaya organisasi terhadap kinerja karyawan sebesar 0,444 , pengaruh langsung gaya kepemimpinan terhadap kinerja karyawan sebesar 0,381 , dan pengaruh langsung komitmen organisasi terhadap kinerja karyawan sebesar 0,324.

Untuk efek tidak langsung dari budaya organisasi terhadap komitmen organisasi melalui kepuasan kerja sebesar 0.277, pengaruh tidak langsung dari gaya kepemimpinan terhadap komitmen organisasi melalu kepuasan kerja sebesar 0,231, pengaruh budaya organisasi terhadap kinerja melalui kepuasan kerja dan komitmen organisasi sebesar 0,90 dan pengaruh gaya kepemimpinan terhadap kinerja melalui kepuasan kerja dan komitmen organisasi sebesar

0,75. Dilihat dari efek langsung dan tidak langsungnya penelitian ini, budaya organisasi yang paling berpengaruh langsung terhadap kinerja karyawan.

Efek total dari budaya organisasi terhadap kepuasan kerja adalah sebebsar 0,461 (sama besarnya dengan efek langsungnya, sebab tidak ada hubungan lain yang dapat mempengaruhi kekuatan budaya organisasi ini), gaya kepemimpinan terhadap kepuasan kerja 
sebesar 0,383, efek langsung kepuasan kerja terhadap komitmen organisasi sebesar 0,602, pengaruh langsung budaya organisasi terhadap kinerja karyawan sebesar 0,444, pengaruh langsung gaya kepemimpinan terhadap kinerja karyawan sebesar 0,381, dan pengaruh langsung komitmen organisasi terhadap kinerja karyawan sebesar 0,324.

\section{PEMBAHASAN}

Analisis data dan pengujian terhadap 6 hipotesis penelitian sesuai modul-modul teoritis yang telah diuraikan pada bab II. Hasil yang diperoleh menunjukkan bahwa semua hipotesis dapat diterima model teoritis telah diuji dan kriteria Goodness Of Fit dan mendapatkan hasil yang baik pengujian dan juga menunjukkan hasil yang tidak menyimpang dari yang dihipotesiskan. Penelitian ini mengembangkan 6 hipotesis yang akan dibuktikan dengan data yang diperoleh. Hasil yang diperoleh dari uji masing-masing hipotesis adalah sebagai berikut :

\section{$\mathrm{H}_{1}$ : Budaya organisasi berpengaruh positif terhadap kepuasan kerja.}

Hasil pengujian hipotesis 1 mendapatkan bahwa parameter estimasi hubungan antara budaya organisasi dengan kepuasan kerja tersebut diperoleh sebesar 0,473. Pengujian menujukkan hasil yang signifikan dengan nilai $\mathrm{C} . \mathrm{R}=4.250$ dengan probabilitas $=0,000$ ( $\mathrm{p}<0,05)$. Hal ini berarti Hipotesis 1 diterima. Dengan demikian hasil penelitian ini sesuai dengan hasil penelitian yang dilakukan oleh Kirk L. Rogga (2001), Jennifer dan Bersade (1997) maupun Soedjono (2005) serta Koesmono (2005).

\section{$\mathrm{H}_{2}$ : Gaya kepemimpinan berpengaruh positif terhadap kepuasan kerja.}

Hasil pengujian hipotesis 2 mendapatkan bahwa parameter estimasi hubungan antara gaya kepemimpinan dengan kepuasan kerja tersebut diperoleh sebesar 0,395. Pengujian menujukkan hasil yang signifikan dengan nilai C.R $=3.617$ dengan probabilitas $=0,000(\mathrm{p}<$ 0,05). Hal ini berarti Hipotesis 2 diterima. Dengan demikian hasil penelitian ini sesuai dengan hasil penelitian yang dilakukan oleh Chruch (1997).

\section{$\mathrm{H}_{3}$ : Kepuasan kerja berpengaruh positif terhadap komitmen organisasional.}

Hasil pengujian hipotesis 3 mendapatkan bahwa parameter estimasi hubungan antara gaya kepemimpinan dengan kepuasan kerja tersebut diperoleh sebesar 0,571. Pengujian menujukkan hasil yang signifikan dengan nilai C.R $=5.509$ dengan probabilitas $=0,000(\mathrm{p}<$ 0,05). Hal ini berarti Hipotesis 3 diterima. Dengan demikian hasil penelitian ini sesuai dengan hasil penelitian yang dilakukan oleh Mowday, Steers dalam Morrison (1997).

\section{$\mathbf{H}_{4}$ : Komitmen organisasional berpengaruh positif terhadap kinerja karyawan.}


Hasil pengujian hipotesis 4 mendapatkan bahwa parameter estimasi hubungan antara gaya kepemimpinan dengan kepuasan kerja tersebut diperoleh sebesar 0,343. Pengujian menujukkan hasil yang signifikan dengan nilai C.R $=3.203$ dengan probabilitas $=0,001(\mathrm{p}<$ 0,05). Hal ini berarti Hipotesis 4 diterima. Dengan demikian hasil penelitian ini sesuai dengan hasil penelitian yang dilakukan oleh Morrison, (1997).

\section{$\mathrm{H}_{5}$ : Budaya organisasi berpengaruh positif terhadap kinerja karyawan.}

Hasil pengujian hipotesis 5 mendapatkan bahwa parameter estimasi hubungan antara budaya organisasi dengan kepuasan kerja tersebut diperoleh sebesar 0,365. Pengujian menujukkan hasil yang signifikan dengan nilai C.R $=3.123$ dengan probabilitas $=0,002(\mathrm{p}<$ 0,05). Hal ini berarti Hipotesis 1 diterima. Dengan demikian hasil penelitian ini sesuai dengan hasil penelitian yang dilakukan oleh Fey dan Denison (2000)

\section{$\mathrm{H}_{6}$ : Gaya kepemimpinan berpengaruh positif terhadap kinerja karyawan}

Hasil pengujian hipotesis 6 mendapatkan bahwa parameter estimasi hubungan antara gaya kepemimpinan dengan kinerja tersebut diperoleh sebesar 0,317. Pengujian menujukkan hasil yang signifikan dengan nilai C.R $=2.164$ dengan probabilitas $=0,006(\mathrm{p}<0,05)$. Hal ini berarti Hipotesis 6 diterima. Dengan demikian hasil penelitian ini sesuai dengan hasil penelitian yang dilakukan oleh Mc Neese dan Smith (1996), Shea (1999) dan Guritno dalam Masrukhin \& Waridin (2006)

Budaya organisasi berpengaruh paling besar terhadap Kepuasan kerja, Kepuasan kerja melalui komitmen organisasional berpengaruh paling besar terhadap Kinerja Karyawan. Simpulan hipotesis dapat dilihat pada Tabel 2 berikut:

Tabel 2 Kesimpulan Hipotesis

\begin{tabular}{|l|l|l|}
\hline & \multicolumn{1}{|c|}{ Hipotesis } & Hasil Uji \\
\hline H1 & Budaya organisasi berpengaruh positif terhadap kepuasan kerja. & Diterima \\
\hline H2 & Gaya kepemimpinan berpengaruh positif terhadap kepuasan kerja. & Diterima \\
\hline H3 & Kepuasan kerja berpengaruh positif terhadap komitmen organisasional. & Diterima \\
\hline H4 & Komitmen organisasional berpengaruh positif terhadap kinerja karyawan. & Diterima \\
\hline H5 & Budaya organisasi berpengaruh positif terhadap kinerja karyawan & Diterima \\
\hline H6 & Gaya kepemimpinan berpengaruh positif terhadap kinerja karyawan & Diterima \\
\hline
\end{tabular}




\section{DAFTAR PUSTAKA}

Cahyono, Dwi, Ghozali I., 2002, Pengaruh Jabatan, Budaya Organisasional, dan Konflik Peran Terhadap Hubungan Kepuasan Kerja dengan Komitmen Organisasi, Jurnal Riset Akuntansi Indonesia, Vol. 5, No. 3.

Ferdinand, Augusty. 2005. Structural Equation Modeling. Semarang, CV. Indoprint.

Fuad, Mas'ud, 2004, Survai Diagnosis Organisasional (Konsep dan Aplikasi). Badan Penerbit Universitas Diponegoro.

Glaser, Susan R; Zamanou, Sonia and Hacker Kenneth, 1987, Measuring and Interpreting Organizational Culture. Management Communication Quartely Vol.1 No.2 pp 173-178. Irwansyah, 2005, Pengaruh Komitmen Organisasional, Kepuasan Kerja, dan Keperilakuan Etis Terhadap Keinginan Berpindah Profesional Sistem Informasi, Jurnal Bisnis Strategi, Vol. 14.

Kadir, dan Ardiyanto Didik, 2003, Pengaruh Komitmen Organisasional Terhadap Kepuasan Kerja dan Keinginan Karyawan Untuk Berpindah, Jurnal Bisnis dan Strategi, Vol. 2.

Kirk L. Rogga, 2001. Human Resources Practices, Organizational Climate and Employee Satisfaction, Academy Of Management Review, July, 619 - 644.

Koesmono, Teman H. 2005, Pengaruh Budaya Organisasi, Terhadap Motivasi dan Kepuasan Kerja Serta Kinerja Karyawan Pada Sub Sektor Industri Pengolahan Kayu Skala Menengah Di Jawa Timur, Jurnal Manajemen \& Kewirausahaan, Vol. 7 No. 2

Linz, Susan J., 2002, Job Satisfaction Among Russian Workers, William Davidson Institute Working Paper, Reseacrh Feelow Wlliam Davidson Institute University of Michigan pp. 8-15.

Lok, Peter, dan Crawford, John, 2004, The Effect of Organizational Culture and Leadership Style on Job Satisfaction and Organizational Commitment, The Journal of Management Development, Vol. 23 No. 4.

Lund, Daulatram B., 2003, Organizational Culture and Job Satisfaction, Journal of Business \& Industrial Marketing, Vol. 18 No. 3.

Mangkunegara, AA Anwar Prabu, 2001, Manajemen Sumber Daya Manusia Perusahaan. Bandung PT.Remaja Rosdakarya.

Masrukhin dan Waridin, 2006, Pengaruh Motivasi Kerja, Kepuasan Kerja, Budaya Organisasi, dan Kepemimpinan Terhadap Kinerja Pegawai, EKOBIS, Vol. 7 No. 2 
Molenaa, Keith, 2002, Corporate Culture, a Study of Form With Outstanding Consideration Safety, Profesional Safety pp. 18-27

Nasarudin, 2001, Job satisfaction and organizational commitment among the Malaysian workforce. Proceeding of 5 th Asian Academic of Management ConferenceKlantan Pahang pp. 270-276.

Pool, Steven W., 1997 The Relationship of Job Satisfaction With Substitutes of Leadership, Leadership Behavior, and Work Motivation, The Journal of Psychology, Vol. 13, May

Ratnasari, Sri Langgeng, 2017 Perencanaan Sumber Daya Manusia. Surabaya: Unggul Pangestu Nirmala Multimedia Press \& Publishing

Samad, Sarminah, 2005, "Unvraveling the Organizational Commitment and Job Performance Relationship: Exploring the Moderating Effect of Job Satisfaction”, The Business Review, Vol. 4, December.

Soedjono, 2005, Pengaruh Budaya Organisasi Terhadap Kinerja Organisasi dan Kepuasan Kerja Karyawan pada Terminal Penumpang Umum di Surabay, Jurnal Manajemen \& Kewirausahaan, Vol. 7, No. 1

Yuwalliatin, Sitty, 2006, Pengaruh Budaya Organisasi, Motivasi, dan Komitmen Terhadap Kinerja Serta Pengaruhnya Terhadap Keunggulan Kompetitif, EKOBIS, Vol. 7 No. 2 